\title{
Language, Ecology and the Stories We Live By: The Ecolinguistics of Tholkappiyam
}

\author{
V Shri Vaishali ${ }^{1} \&$ Dr. S. Rukmini ${ }^{2}$ \\ ${ }^{1}$ Research Scholar, Department of English, School of Social Sciences and Languages, VIT, Vellore. \\ venkatshrivaishali@gmail.com 9940805789 Orcid id: 0000-0001-7843-9521 \\ 2 Sr. Assistant Professor, Department of English, School of Social Sciences and Languages, VIT, \\ Vellore.rukminikrishna123@gmail.com Orcid Id: 0000-0001-8414-3145. \\ Corresponding Author: Dr. S. Rukmini
}

\begin{abstract}
The term "ecolinguistics" is relatively a recent discussion with Eliar Haugen (1972) bringing up the concept of "The ecology of Language". Since then, various methods and approaches to the field has been suggested to study the language-ecology interaction, primarily from the west. As a result, ecolinguistics is conceived as a new-born western discipline. However, Ecolinguistics, as the term suggests is the specialized study of language-ecology interaction. The "feeling" of the existence of the necessary relationship between language and ecology even before makes us ask the question if the concept of ecolinguistics has not been discussed by linguists before $20^{\text {th }}$ Century. The ancient Tamil linguistic treatise called Tholkappiyam (dated between $6^{\text {th }} \mathrm{BCE}$ to $8^{\text {th }} \mathrm{CE}$ ) presents the fundamental nature of the relationship between ecology, language and culture through the theory called Tinai. The paper primarily draws attention to look into the linguistic philosophy of Tholkappiyam through an ecological perspective. From the ecolinguistic perspective, the paper analyses Tinai based on three criteria: Ecosophy, Aspects of Language-ecology-culture interaction and the theoretical framework of Tinai. Having analysed from the aforementioned criteria, the paper advocates that the framework of Tinai can contribute to the ecolinguistic studies parallel to the philosophies of Edward Sapir (1912) and Hagege (1985).
\end{abstract}

Keywords: Ecolinguistics, Tinai theory, Ecosophy, Language Ecology, Critical Discourse Analysis, Tholkappiyam.

\section{Introduction:}

The term "ecolinguistics" in the academic enquiry is subject to interpretations and multiple definitions. According to international ecolinguistic association, "ecolinguistics explore the role of language in life-sustaining interactions of humans, other species and the physical environment." Arran Stibbe (2015) defines that "ecolinguistics analyses language to reveal the stories we live by,

This Open Access article is published under a Creative Commons Attribution Non-Commercial 4.0 International License (http://creativecommons.org/licenses/by-nc/4.0/), which permits non-commercial re-use, distribution, and reproduction in any medium, provided the original work is properly cited. For citation use the DOI. For commercial re-use, please contact editor@rupkatha.com. 
judges those stories according to an ecosophy, resists stories which oppose the ecosophy, and contributes to the search for new stories to live by." Sibo Chen (2016) defines that "ecolinguistics seeks to explore linguistic phenomena found in inter-language, inter-human, and human-nature relationships from the perspecties of ecological philosophy." As Arran Stibbe (2015) points out, the studies related to ecolinguistics are mostly "met with bafflement". Not just because ecolinguistics brings ecology and language together, which were so far considered to be distinct areas but also because "ecolinguistics" does not confine itself to a unidirectional method and approach. Therefore, the meaning of the word, ecolinguistics, has been so far fluid, giving the room for multiple, mutually exclusive approaches and methods. This may include the studies related to semiotics, studies on the influence of environment on the language and its vocabulary, studies related to the influence of language on the environmental issues and so on. However wider and different, in a nutshell, the term "ecolinguistics" is defined to be a study on the interaction between language and ecology. Arran Stibbe (2015) finds that such wider perspectives and approaches of ecolinguistics is majorly because of the various interpretations to the word ecology among the ecolinguists. Steffenson and Fill (2014) also echo such understanding, as they come up with four different interpretations of the word ecology in the ecolinguistic study. According to Steffenson and Fill (2014), the term "ecology" owns four interpretations or approaches, which determines the ecological philosophy of an ecolinguistic study. The first approach is called symbolic ecology. Here, the word "ecology" does not denote the physical or environmental aspects of it. This approach discusses the interaction between different languages in a multilingual setup. The word "ecology" symbolizes the simultaneous presence of various languages and its interaction among each other. The second approach is called sociocultural ecology. Here, the term "ecology" denotes the sociocultural aspects of the place the language belongs to, and the interaction of the language with the respective societies and culture. The third approach is called cognitive ecology. This discusses the cognitive abilities and characteristics of the organism and its interaction with or influence on the linguistic characteristics of the respective languages. The fourth is a well-known and a common approach towards the meaning of the word ecology which refers to the physical characteristics and biological aspects of the respective environment. So, this approach tends to focus on the interaction between the language and the physical environment. With different approaches to the term ecology, the focus on its interaction with language can vary according to each study and each approach. Multiple research frame works and terms have been coming up in ecolinguistic study based on their interpretation of the word ecology. For instance, aligned to the intentions of the fourth interpretation, Jorgen Bang (2014) has drafted a philosophical framework for the ecolinguistic study. According to Bang (2014), ecolinguistics the research framework for an ecolinguistic study should be based on six significant ideals. He claims that ecolinguistics should be "contributing to a local and global culture in which (i) co-operation, (ii) sharing, (iii) democratic dialogue, (iv) peace and non-violence, (v) equality in every sphere of daily life, and (vi) ecological sustainability are the fundamental features and primary values." Like ecology, the word ecosophy (which blends the two words: ecology and philosophy) plays a crucial role in the ecolinguistic study. While Naess (1995) uses the term "ecosophy", he means the "philosophy of ecological harmony." The term "ecosophy" was later used in Stibbe's definition to ecolinguistics, where he defines the study as judging stories according to an ecosophy and restricting the stories that oppose the ecosophy. Arran Stibbe (2015) claims that "All ecolinguistic studies are based on an ecosophy, although the ecosophy can 
be implicit or explicit. Different ecolinguists will use different ecosophies to provide the criteria for judging discourses, and an individual linguist's ecosophy is likely to evolve and change over time as they are exposed to both a wide range of discourses and direct experiences of the natural world." By bringing Naess's ecosophy to the definition of ecolinguistics, we can understand that the ecolinguistic studies, from Stibbe's perspective, should aim for a linguistic, ecological and philosophical harmony. Therefore, with multiple approaches and interpretations to the meaning of the word ecology, the term "ecolinguistics" tends to provide a widely varied, multidirectional, and mutually exclusive interpretation for itself, making its definition fluid and wide. Owing to such multiple approaches and methods related ecolinguistic study, Todd LeVasseur (2014) conducts a survey in the language and ecology forum to understand the whether ecolinguistics "can proceed as a confident new movement with a united purpose, or a more disparate collection of approaches united more or less by a common viewpoint, or perhaps a set of entirely different approaches which confusingly have the same name". Through the question: How do you define ecolinguistics?, he comes across various interpretations of the word. The most popular response to the question that was recorded was: Ecolinguistics is the "Study of the interdependence of language and the perception/interpretation of the natural world we live in". From the above definitions, we can understand that though the researchers were able to discrete and explore the relationship between language and ecology, there were certain apprehensions to arrive at a uniform definition because of the fluidity it holds to the certain other aspects of various disciplines.

Hence, owing to the wider and non-confirmed notion of ecolinguistic study, later, Arran Stibbe (2015) explains that "each ecolinguist will have their own set of philosophical principles they use to judge stories against, reflecting their own values and priorities, but all will have in common a consideration of the interrelationships of humans with other organisms and the physical environment."

\section{The Ecolinguistic Traditions:}

However fluid and wide the definition of Ecolinguistics is, the researches in this discipline can be conveniently classified under any of three major theoretical strains of Ecolinguistics. Todd LeVasseur (2014) has mentioned that the theories of Ecolinguistics can be broadly classified into three major traditions. However all the three traditions are related to one another with their common objective of connecting language and ecology, they are mutually exclusive too. These traditions are: The Haugenian, the Hallidayan, and the Biolinguistic.

The enquiry into ecolinguistics started with "The ecology of language" proposed by Eliar Haugen, an American Linguist in 1972. The language ecology of Haugen contains three aspects (Sibo Chen, 2016). The first among them is symbolic. This discusses the co-existence of the symbolic systems in the multi-language context. The other part of language ecology is psychological. Haugen (2001) defines it as the "interaction with other languages in the minds of bi and multilingual speakers." The third part or aspect of language ecology, according to Haugen, is sociological. This aspect is concerned with the "interaction of the language with the society in which it functions as a medium of communication." In Haugen's perspective to language ecology, the word ecology is majorly used in the metaphorical sense where the ecology of language is human centric, and how it is taken to become the part of the larger environment from the humans. 
As Haugen (2001) clearly defines it to be "primarily determined by people, who learn it, use it and transmit to others."

The second tradition is called Hallidayan, pioneered by Micheal Halliday. The ecolinguistic perspectives of Halliday was first expressed at the Thessaloniki World Conference of Applied Linguistics in 1990. While Haugen used the concept of ecology as a metaphor to language, Hallidayan tradition directly brought environmental and ecological problems to language. Halliday attempts to shift the usage of language from anthropocentric to ecocentric which will in turn give the possibility of a degradation in a human being's unecological conducts. So the researches in Hallidayan tradition happen to position themselves under Critical Discourse Analysis (Sibo Chen, 2016). So, the Hallidayan theoretical strain has brought eco-criticism to language studies, which in turn introduced ecological responsibilities to language. This theoretical strain intends to offer "methodological contributions to creating ecological awareness."

The third tradition, as mentioned by Todd LeVasseur (2014) is the biolinguistic strain of ecolinguistics. This strain was pioneered by Nettle and Romaine (2002). Nettle and Romaine (2002) through the term "biolinguistic diversity" connectes the extinction of language to the extinction of bio-diversity. The biolinguistic diversity attempts to "capture the interaction of humans and their cultures, including especially their languages, discourses, and coded conceptions of the more-than-human world, and how these both shape and are shaped by the more-than-human world." They show an instance of how agricultural and industrial revolution has brought a "hegemonic languages and fashions" that has in turn led to the extinction of linguistic and cultural diversity.

As each of the major theoretical strains are mutually exclusive with different objectives, ecolinguistics can be clearly understood to be an umbrella term for every possible research that discusses the interaction and connection between language and ecology under different aspects. However, through the light of three major theoretical strains, any form of language-ecology interaction that ecolinguistics can be streamlined to come under any of the above three ecolinguistic traditions (Sibo Chen, 2016). This also helps in restraining the fluidity and nonconfirmity in the definition of the term ecolinguistics. However, due to the mutual exclusiveness of these three major theoretical strains, an argument of which among them is very close to the intent of the ecolinguistics exists among the ecolinguists.

\section{The Tholkappiyarian Tradition Of Ecolinguistics:}

By drawing the timeline of the major theoretical traditions and definitions of ecolinguistics, we can find that the discipline has come up only in the late $20^{\text {th }}$ century in the West. But we can understand that interaction between language and ecology should be as old as the language itself through our general cognition about language and universe. Such inference also brings the need to acknowledge and look for the traces of ecolinguistics in academia from the periods earlier. Although we can trace the discussions of ecolinguistics in the west around late $20^{\text {th }}$ century, we can find an extensive description about language-ecology interaction in the earlier Tamil literature called Tholkappiyam that belongs to the sangam period of Tamil. 
5 | Language, Ecology and the Stories We Live By: The Ecolinguistics of Tholkappiyam

Tholkappiyam is an ancient Tamil treatise and the one of the fewests living ancient texts from the Tamil Sangam period that discusses the linguistic elements of Tamil language. The period of Tholkappiyam is not clearly traced yet. But the estimation ranges between $6^{\text {th }}$ BCE to $8^{\text {th }}$ CE. Therefore, the treatise has also become the only major source of linguistic instruction to understand and study the grammar of Tamil language. Although, there are other Tamil language treatises like Akapporul, Yapparungalam, Yapparungalakkaarigai, the treatise of Tholkappiyam is usually identified as the monopoly of Tamil linguistics. Such monopoly that comes through the diversification of knowledge is found in this ancient Tamil treatise. The treatise of Tholkappiyam consists of three books: Ezhuthadhigaram, Solladhigaram and Porulathigaram. The word Ezhuthu in the first book of Ezhuthadhigaram means letters or alphabets. Therefore, this book is a book on orthography. Interestingly, the first book gives a detailed account on the phonology also, as Tamil, like every Indian language, has phonemic orthography. The second book of Tholkappiyam is called Solladhigaaram which discusses the morphology of Tamil language. The third book Poruladhigaaram deals with semantics and poetics of the Tamil language. To understand the significance of the third chapter, it is also essential to look into the meaning of the word Porul. "Porul" conveys two meanings: 1. Material wealth 2. Meaning. However, the second meaning also extends to mean "content". The third book of the treatise discusses the content of the poetry and also the strategies and devices that helps in building the meaning and content. And it is in the third book, the relationship between ecology and language, ecology and poetry is discussed. The popular theory on Discourse Analysis, called Tinai, discusses the role of ecology on language and poetics. The word Tinai has multiple meanings. But primarily, in the tholkappiyarian context, it means land tract and mode of love behavior.

Again, to understand the ecolinguistic aspects of Tholkappiyam, the paper attempts to study the Tinai theory and the Porulathigaram of Tholkappiyam under three different criteria, which are very significant to the researches in ecolinguistics.

1. The impact of ecology on language and culture

2. The ecosophy of Tinai.

3. The eco-theoretical framework of Tinai.

\section{The Ecological Impact On Language And Culture:}

Although the aforementioned discussions on ecolinguistics discuss the relationship between ecology and language, the role of society and culture is always implicit in the way we approach ecolinguistics. While talking about the roots of ecolinguistics, Alwin Fill (2001) draws back to Edward Sapir's essay "Language and Environment". Fill and Muhlausler (2001) comment that "If ecolinguistics is based on the principles of interaction and diversity, Sapir is an early exponent of ecolinguistics in so far as he points out the relation between physical and social environment on the one hand, and language and culture on the other." Sapir's 1912 essay called "Language and Environment" gives a detailed note on how language is based on and influenced by the respective larger physical and social environment of the language. Again the very first definition of "ecolinguistique" given by Hagege in 1985 contains the significant word "culture". Hagege (1985) defines ecolinguistics as the study of "how natural phenomena like topographical characteristics, relations between humans, other organisms and cosmic phenomena are integrated in to language 
and culture." Interestingly, the "undated" (popularly believed to be belonging to $5^{\text {th }}$ or $6^{\text {th }}$ CE) Tamil linguistic treatise Tholkappiyam suggests a theory that is parallel to the ideas of Edward Sapir and Hagege.

To understand how, an introspection into the theory of Tinai is required. The Tamil word Tinai does not carry a word for direct translation in English. However, it can mean landscapes. But in a deeper perspective, the Tinai theory discusses the relationship between landscape and lifestyle. In the English transation of Tholkappiyam, Murugan V suggests three different linguistic meanings of the word Tinai, which are "1. The akam/puram spheres of human life as structured in a composition, 2. The landscape as an appropriate natural backdrop to the given akam thematic situation or the mode of love behavior, 3. Word-class being known as uyartinai and akrinai." The porulathigaram of Tholkappiyam where the Tinai theory is discussed consists of two categories: Akapporul and Purapporul. The word akam in Tamil means inside or internal and Puram, outside or external. The akapporul of Tholkappiyam deals with the modes of behaviours of love and the purappora/on politics, administration and the lifestyle of people. Each of the categories have their own Tinais. In akapporul, the Tholkappiyam discusses 7 kinds of Tinai: Kurinji, Mullai, Marudham, Neidhal, Paalai. In Purapporul, there are other 7 tinais called vetchi, vanji, uzhignai, thumbai, vaagai, kaanchi, and paadaan. In the akapporul, Tinai refers to both landscape and livelihood and in the puram, the word - Tinai implies the livelihood of people alone. However, in both the categories, the significance of flora, fauna and the topography in poetics is emphasized. The landscape denoting Tinais in the akapporulare: 1. Kurinji, the hilly tract, 2. Mullai, the forest tract, 3. Marudham, the cultivable tract, 4. Neidhal, the regions surrounded by the sea, 5. Paalai, the dry land. These are famously called as "ainnilangal" in Tamil, which means the "five lands".

"Avatrul Naduvan Aindhinai

Naduvanadhu Ozhiya

Padudhirai Vaiyam Paaththiyap panbe." (Tholkappiyam, verse 947)

which gets translated in English as:

"The sea-girt world

stands apportioned,

To the middle five of these strands" (Translated by V Murugan (2000))

Now, discussing the impact of ecology on culture, the direct relationship between the land and lifestyle is shown in the akapporul of the porulathigaaram in Tholkappiyam. Here, the love behavior of the people in land is defined according to the nature of the land. According to Tholkappiyam and the Tinai theory, the expression of love is majorly determined by the nature of topography. The rule laid by the Tholkappiyam on the mode of love behavior according to the tracts are called Uripporul.

"Punardhal Piridhal iruththal irangal

Oodal, avatrin nimitham endrivai

Thinaikku Uripporule." (Tholkappiyam, verse no. 962) 
7 | Language, Ecology and the Stories We Live By: The Ecolinguistics of Tholkappiyam

which is translated into English as:

\section{"Union, Separation, Endurance, \\ Pining and Sulking,}

And the motives there in

Are perceived to be the strands of Akam love behavior". (V Murugan, 2000)

In Uripporul, each tract is assigned with an exclusive mode of love behavior due to the ecological conditions of the tract. The Tinai theory propounds that the ecological conditions of the land like season, weather and other characteristics play a significant role in the mode of love behavior of the people. The following table depicts the nature of the tract and the respective mode of love behavior.

\begin{tabular}{|l|l|l|}
\hline Tinai & Nature of the land & Mode of Love Behaviour \\
\hline Kurinji & The Hilly Tract & Union \\
\hline Mullai & The Forest Tract & Separation \\
\hline Marudham & The Cultivable Tract & Endurance \\
\hline Neidhal & The Littoral Tract & Pining \\
\hline Paalai & The Arid Tract & Sulking \\
\hline
\end{tabular}

Tab 1. The Akattinaiyiyal

Through assigning a mode of love behavior for each tract, the Tinai theory insists to show the real nature of relationship suitable to each topography. For instance, in the neidhal Tinai, which is a land by the sea, the major occupation of the thalaivan/hero is "going to the sea for fishing". As the thalaivan goes for fishing, the thalaivi is alone pining for her love to come back. So, the Tinai theory suggests that a love poetry which has the neidhalland as its setting should highlight the emotion of pining in the thalaivan-thalaivi romance.

While the akatttinai discusses the direct relationship between the five tracts and love behavior, the purattinai is not directly associated with the lands. However, they discuss the ecological characteristics in the purattinai. Despite discussing the governance and the mode of war, the tinais are named after the flowers and trees, specific to the land. The names of the flowers, wore by the King during the war, are usually the names of the Tinai. Interestingly, although there are different modes of war, the purattinai wars were raged majorly to capture the flora and fauna of the particular land. Each of the tinai has substrands and it is also influenced by the ecological characteristics of the given land.

"...Utku Varaththondrum eer-eazhth thuraiththe." (Tholkappiyam Verse no. 1005)

which in English means

"... And it ramifies into fourteen substrands of awesome nature" (V Murugan, 2000) 
For instance, in the vetchi mode of war, which is usually raged in the hilly tracts, the intention of the war is to capture the mammals of the enemy's land. Since, the mammals can be raised well in the hilly region, the war in vetchi tinai measures its success by the capturing of the mammals.

"Vendhu vidu munaignar vepatruk kalavin

Aa thandhu oambal mevatru aagum. (Tholkappiyam, Verse no. 1006)

which is translated into English as:

"Vetci is

Men at the border posts,

Charged by their ruler,

Capturing the cows of hostile king by stealth

And keeping them right underguard." (Murugan V, 2000)

Similarly, uzhignai thinai is identified with the cultivable tract. According to the uzhignai thinai, the mode of the war is to break the fort of the enemy and to cultivate their own crops in the enemy's land. Similarly, the other Purattinais and the ethics and mode of war discussed by them are highly concerned with the ecological characteristics of the land. Hereby, the tinai theory suggests that the mode of war and the king's intention of the war is highly determined by the ecological characteristics of the respective land.

\section{The Ecosophy Of Tinai:}

As Naess (1995) has implied, ecosophy means the "philosophy of ecological harmony". In simipler terms suggested by Arran Stibbe (2015), ecology means "living". Although, it looks ambiguous on a surface level when one means ecosophy to be living, on a deeper understanding, ecosophy is the harmonious framework for living in line with the ecological characteristics of the respective environment. Now, this can be the summary of the wide Tinai theory in a sentence: Living harmoniously with the characteristics of the landscape. As mentioned, the major implication of Tinai theory is the haromious co-existence of language and culture in accordance with the ecology and landscape. Aran Stibbe (2015) explains three different spectrums of ecosophy for an ecolinguistic study. 1. From Anthropocentric to ecocentric end, 2. From neoliberal end to socialist, localist and anarchist end. 3. from optimistic to pessimistic end. Among the three spectrums, Tholkappiyam is based on the first one. Since Tinai is a theoretical guideline to the poetics of sangam literature, it believes that the story should be based on the ecological characteristic of each tract. This, in turn, brings the discourse to move from the basing the anthropocentric content of the story based on the eco-centric dimensions of each tract, which was already laid in the Tinai theory.

"Nilam neer vali visumbodu aintum

Kalandha mayakkam ulagam aadhalin

Irutinai aimbaal iyalneri vazha-amaith 
9 | Language, Ecology and the Stories We Live By: The Ecolinguistics of Tholkappiyam

Thirivu il sollodu thazhaa-al vendum." (Tholkappiyam, Verse no. 1581)

As translated by Murugan V (2000), the linguistic convention of Tholkappiyam is as follows:

A structured blend of

Earth, fire, water, air and space,

As the world is,

The use words are made of,

Must be undistorted,

Undeviating from the norms

That go with the classification of

The human - non-human generic distinction,

And the five genders thereof. (V Murugan, 2000)

Every ecosophy has its own prescription to make the philosophy functional. Tholkappiyam does it through a rigid theoretical framework for the harmonious relationship between nature and lifestyle. Following are the fundamental characteristics that build the ecosophy of Tinai theory as highlighted in Tholkappiyam.

1. Harmonious Living: Tinai theory implies that the content of poetry is valid only if it stays through the fundamental characteristics of the landscape the poetry belongs to. This includes the primary time of the landscape, the primary occupation of the people there, the predominant flora and fauna of the landscape and much more.

2. Clarity in the understanding of the characteristics of each landscape: The ecosophy of Tinai insists in the clear and deep understanding of the lifestyle of each tract through the concepts called mutal porul, karupporul and uripporul. Through an unambiguous layout on the characteristics of each tract, it helps with the scope and limitations of the lifestyle of each tract, which can be converted into poetry.

3. Rigid distinction: The tinai theory does not have a room for the characteristics of one landscape to be mixed up with the other. There is a rigid distinction in the ecological characteristics of each tract and the blending of two different characteristics is considered as the breach of rules. As Tholkappiyar lays,

"Marabu Nilaith thiriyaa Maatchiya aagi

Viravum Porulum Viravum Enba." (Tholkappiyam, Verse no. 994)

meaning,

"Where they do not entail

Breach of the conventions set,

There are blendings of features 


\section{Of land and time and flaura and fauna \\ Marked region-specific and culture specific}

So has it been laid down." (V Murugan, 2000)

As the meaning of the verse explains, the conventions of living, as laid in the poetics of Tholkappiyam according to Tinai theory is "marked region-specific and culture specific". This implies that even the primary time and season is landscape based. As the primary time and season differs from each tinai, based on the nature of the landscape and it differs on the way of lifestyle of people living in each Tinai. By the characteristics of time and season, Tinai theory means the primary time of the day, which seems to span longer and the primary season of the year which tends to stay longer according to each landscape. For instance, in the forest regions (mullai), the primary time is evening and the primary season is rainy. Likewise, each tract has its own primary region and time, which can be understood through the theoretical framework of Tinai. Tinai theory believes that the primary time and season cannot be changed between the landscapes, and therefore the lifestyle of each landscape is unique and cannot be mixed with the other. As Tholkappiyar mentions:

"Tinai mayakkuruthalum kadi nilai ilave

Nilai orungu mayangudhal ilai ena mozhiba-

Pulan nanku unarndha pulamaiyore." (Tholkappiyam, Verse no. 960)

which means,

"That

Aspects of land and time

Assigned to a given tract

Do get mixed with those of another tract

Is no deviation unacceptable." (V Murugan, 2000)

Through the rigidity in the relationship between landscape and time, the Tinai theory brings a strict harmonious relationship that has to be followed in the discourses. As a result, the stories of each landscape should stay true to the possibilities of activities in the respective sirupozhudhu (time) and perumpozhudhu (season), and the lifestyle of people associated with the time and season.

\section{The Eco-Theoretical Framework Of Tinai}

"Harmony" is the keyword to summarize the elementary principles suggested in the Tinai theory. The theory brings a three tier structure to establish and sustain the ecological harmony in people's lifestyle. The three tier structure of the Tinai theory are called: Mutalporul, Karupporul, Uripporul. Mutalporul refers to the primary space and time. The space/land is divided into Kurinji, Mullai, Marudham, Neidhal and Paalai. The time (Pozhudhu) is further divided into two: 1. Sirupozhudhu (Primary time of the day), 2. Perumpozhudhu (Primary season of the year). Under Sirupozhudhu 
and Perupozhudhu, the Tinai theory suggests 6 further categories. The six kinds of Sirupozhudhu are 1. Vaigarai or the early morning, 2. Kaalai or the morning, 3. Nanpagal or the noon, 4. Erpaadu or the afternoon (when the sun sets), 5. Maalai or the early night, 6. Yaamam or the midnight. Under Perumpozhudhu or the seasons, there are 6 different seasons explained: 1. Ilavenil or the early summer, 2. Mudhuveni or the late summer, 3. Kaar or the rainy season, 4. Koodhir or the Cold season, 5. Ilavenil or the early winter, 6. Mudhuvenil or the late winter. Karupporul includes Flora, Fauna, and the other lifestyle markers specific to the topography. Ten markers determine the karupporu/ of the land. They are: 1. The primary food of the land (unavu), 2. The most common animals in the land (maa), 3. The most common trees of the land (maram), 4. The most common birds of the land (pul), 5. The style of music exclusive to the land (pan), 6. The most common flower of the land (poo), 7. The predominant waterbody of the land (neer), 8. The kind of air instrument played on the land (parai), 9. The primary occupation of the people in the land (vinai), and 10. The most common deity worshipped according to the land (deivam). Thirdly, Uripporul is the mode of love behavior exclusive to each land. Therefore, the theoretical structure of the Tinai theory can be depicted through the following diagram:

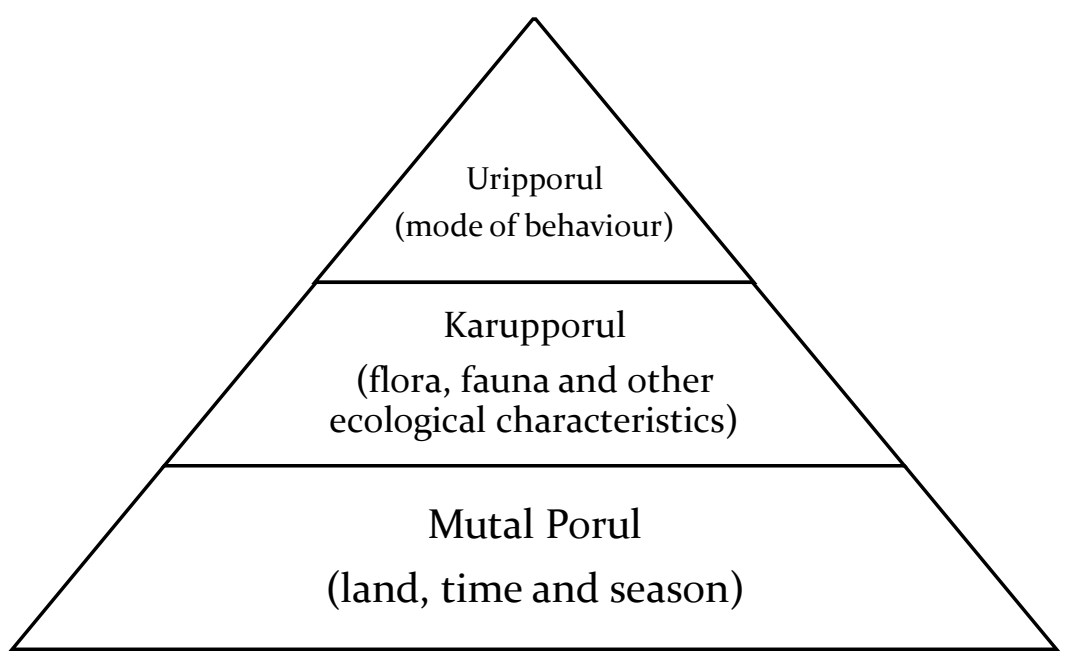

Fig. 2. The Eco-theoretical Structure of Tholkappiyam

Although, the theory initially describes the three-tier structure, the elements in each of the structure vary according to the respective tracts or tinai. The following are the respective mutalporul elements to each tinai.

\begin{tabular}{|l|l|l|l|}
\hline Tinai & The Tract & Sirupozhudhu/Time & Perumpozhudhu/Season \\
\hline Kurinji & Hilly & Nallirul/ Midnight & Koodhir/ Cold \\
\hline Mullai & Forest & $\begin{array}{l}\text { Maalai/ Evening } \\
\text { Twilight }\end{array}$ & Kar/ Rainy \\
\hline Marudham & Cultivable & $\begin{array}{l}\text { Vaigarai / Morning } \\
\text { Twilight }\end{array}$ & All the six seasons \\
\hline
\end{tabular}




\begin{tabular}{|l|l|l|l|}
\hline Neidhal & Littoral & Erpaadu / Afternoon & All the six seasons \\
\hline Paalai & Arid & Nanpagal/ Noon & Venir/ Summer \\
\hline
\end{tabular}

Table 2. Mutalporul

Similarly, the theory brings an exclusive topography-culture relationship as seen in the Tab 3.1. The three-tier structure in the theoretical framework of Tholkappiyam brings an order to the harmony. By keeping the Mutalporul or topography as the base, it suggests that there is a direct impact on the nature of living and other topographical elements, respective to the mutalporul in the karupporul.

\begin{tabular}{|c|c|c|c|c|c|}
\hline $\begin{array}{l}\text { The } \\
\text { Karupporul } \\
\text { Elements }\end{array}$ & $\begin{array}{l}\text { Kurinji/ } \\
\text { The Hilly } \\
\text { Tract }\end{array}$ & $\begin{array}{l}\text { Mullail The } \\
\text { Forest Tract }\end{array}$ & $\begin{array}{l}\text { Marudham/ } \\
\text { The } \\
\text { Cultivable } \\
\text { Tract }\end{array}$ & $\begin{array}{l}\text { Neidhalif } \\
\text { The Littoral } \\
\text { Tract }\end{array}$ & $\begin{array}{l}\text { Paalail } \\
\text { The Arid } \\
\text { Tract }\end{array}$ \\
\hline $\begin{array}{l}\text { The Most } \\
\text { Common } \\
\text { Flower }\end{array}$ & $\begin{array}{l}\text { Kurinji, } \\
\text { Vengai }\end{array}$ & $\begin{array}{l}\text { Mullai, } \\
\text { Pidavam }\end{array}$ & Marudham & Aambal & Paalai \\
\hline $\begin{array}{l}\text { The Most } \\
\text { Common } \\
\text { Animal }\end{array}$ & $\begin{array}{l}\text { Leopard, } \\
\text { Elephant. }\end{array}$ & Deer, Rabbit & Buffalo & Shark & $\begin{array}{l}\text { Injured and } \\
\text { week } \\
\text { Elephant, } \\
\text { Wolf, } \\
\text { Leopard }\end{array}$ \\
\hline $\begin{array}{l}\text { The Most } \\
\text { Common } \\
\text { Bird }\end{array}$ & $\begin{array}{l}\text { Parrot, } \\
\text { Peacock. }\end{array}$ & Cock & Swan & Crow & Eagle \\
\hline $\begin{array}{l}\text { The Primary } \\
\text { Food }\end{array}$ & $\begin{array}{l}\text { Millets and } \\
\text { mountain } \\
\text { paddy. }\end{array}$ & Millets & Paddy & Fish & $\begin{array}{l}\text { Food } \\
\text { through } \\
\text { plunder }\end{array}$ \\
\hline $\begin{array}{l}\text { The Most } \\
\text { Common } \\
\text { Plant }\end{array}$ & $\begin{array}{l}\text { Vengai, } \\
\text { Kongam }\end{array}$ & $\begin{array}{l}\text { Kondrai, } \\
\text { Kaayaa }\end{array}$ & $\begin{array}{l}\text { Marudhu, } \\
\text { Kanji }\end{array}$ & $\begin{array}{l}\text { Punnai, } \\
\text { Kaidhai }\end{array}$ & $\begin{array}{l}\text { Paalai } \\
\text { Iruppai, Kalli } \\
\text { Koorai }\end{array}$ \\
\hline $\begin{array}{l}\text { The Primary } \\
\text { Waterbody }\end{array}$ & $\begin{array}{l}\text { The } \\
\text { Waterfalls. }\end{array}$ & $\begin{array}{l}\text { Forest } \\
\text { Stream }\end{array}$ & River Water & $\begin{array}{l}\text { Backwater, } \\
\text { Sea water. }\end{array}$ & $\begin{array}{l}\text { Aruneersunai } \\
\text { Or A sparsely } \\
\text { water- } \\
\text { flowing } \\
\text { stream. }\end{array}$ \\
\hline
\end{tabular}


13 | Language, Ecology and the Stories We Live By: The Ecolinguistics of Tholkappiyam

\begin{tabular}{|c|c|c|c|c|c|}
\hline $\begin{array}{l}\text { The Primary } \\
\text { Occupation }\end{array}$ & $\begin{array}{l}\text { Collecting } \\
\text { honey, } \\
\text { Harvesting } \\
\text { root } \\
\text { vegetables. }\end{array}$ & $\begin{array}{l}\text { Cattle } \\
\text { keeping. }\end{array}$ & $\begin{array}{l}\text { Ploughing, } \\
\text { Cultivating. }\end{array}$ & $\begin{array}{l}\text { Fishing and } \\
\text { Salt making }\end{array}$ & $\begin{array}{l}\text { Looting and } \\
\text { Plundering }\end{array}$ \\
\hline $\begin{array}{l}\text { The Primary } \\
\text { Deity }\end{array}$ & Murugan & $\begin{array}{l}\text { Thirumal/ } \\
\text { The Vishnu }\end{array}$ & Indhiran & Varunan & Kotravai \\
\hline The people & Vettuvar & $\begin{array}{l}\text { Aayar, } \\
\text { Aaichiyar }\end{array}$ & Uzhavar & Paravatar & Maravar \\
\hline $\begin{array}{l}\text { Wind } \\
\text { Instrument/ } \\
\text { Parai }\end{array}$ & Thandakam & Earugotparai & Nellariparai & Naavaayparai & Aralaipparai \\
\hline $\begin{array}{l}\text { Yaazh/ } \\
\text { The String } \\
\text { Instrument }\end{array}$ & Kurinji yaazh & Mullai & Marudham & Neidhali & Paalai \\
\hline The Music & Kurinji & Catari & Marudham & Neidhal & Paalai \\
\hline $\begin{array}{l}\text { Name of the } \\
\text { Settlement }\end{array}$ & Sirukudi & Seri, Padi & Oor & $\begin{array}{l}\text { Pattinam, } \\
\text { Pakkam }\end{array}$ & Parantalai \\
\hline
\end{tabular}

Tab 3. Karupporul

As one can see in the above table, we can understand how the Tinai theory classifies culture and way of living according to the topography, bringing a harmonious theoretical framework for the discourse. This further extends to the uripporul of the akattinaiyiyal, which was already explained in the Table 3.1.

Through bringing a clear classifications and three-tier structure, the tholkappiyam brings an exclusive attention to topography and how the elements of the story should be framed according to each topography. Therefore, the framework, along with maintaining an ecology in the story, brings also the authenticity to the story.

\section{Conclusion}

Through the existing studies in ecolinguistics, it can be understood that it has a wider scope with varied streams and foci of study. From Todd LeVasseur's (2014) perspectives on ecolinguistic tradition, one can affirm that the focus of an ecolinguistic study can be based on 1. the existence of multiple languages in a specific place, where the word ecology is used as a metaphor, 2. Ecocritical, where the language is studied and analyzed with the intention of ecological harmony, 3. Or studying the focus on the extinction of languages like biodiversity extinction. When all the 
above three traditions were mutually exclusive, they have all agreed with the common idea of language-ecology interaction, which is the fundamental characteristic of ecolinguistics. The aspects of ecolinguistics discussed in Tinai and Tholkappiyam may not belong to the above tradition but stay close to the ideas of Edward Sapir (1912) and Hagege (1985). Hagege (1985) defined ecolinguistique as the study of "how natural phenomena like topographical characteristics, relations between humans, other organisms and cosmic phenomena are integrated in to language and culture." The ecosophy of Tinai and Tholkappiyam can be summarized through the above stated Hagege's definition. Similarly, Tholkappiyam suggests rules parallel to the ecolinguistic ideas of Edward Sapir (1912). Edward Sapir (1912) states that "the physical environment is reflected in language only in so far as it has been influenced by social factors. The mere existence, for instance, of a certain type of animal in the physical environment of a people does not suffice to give rise to a linguistic symbol referring to it. It is necessary that the animal be known by the members of the group in common and that they have some interest, however slight, in it before the language of the community is called upon to make reference to this particular element of the physical environment. In other words, so far as language is concerned, all environmental influence reduces at last analysis to the influence of social environment." We can find Sapir's concern being reflected in the Mutalporul-KarupporulUripporul analytical structure of Tholkappiyam. Sapir (1912) states that "Language may be influenced in one of three ways: in regard to its subject matter or content, i.e. in regard to the vocabulary; in regard to its phonetic system, i.e. the system of sounds with which it operates in the building of words; and in regard to its grammatical form, i.e. in regard to the formal processes and the logical or psychological classifications made use of in speech. Morphology, or the formal structure of words, and syntax, or the methods employed in combining words into larger units or sentences, are the two main aspects of grammatical form." Similarly, as Tholkappiyam discuss the exclusive content for each tract in its Uripporul, it also discusses that the vocabulary of the region differs according to its ecological factors. In the verse 968, Tholkappiyam suggests,

"Peyarum vinaiyum endru aayiru vagaiya

Thinaidhorum maree-iya thinai nilaippeyare." (Tholkappiyar, Verse no. 968)

which means:

"The persons that people of a tract of land

Have names specific to that region,

These names fall into two categories:

Names in tune with the mores of the region

And names derived from the occupation of the region." (V Murugan, 2000)

Therefore, we can find that the names of the people and the settlement vary according to each Tinai in the Karupporu/table. Therefore, it can be affirmed that the tholkappiyarian tradition of ecolinguistics studies language from an ecocentric way and propounds a theory that as the livelihood and culture change according to the tracts, they have an impact in the language and content. The theoretical framework of Tholkappiyam can also help in building further frameworks for ecolinguistics in critical discourse analysis. Arran Stibbe (2015) defines the hyphenated 
"stories-we-live-by" as the "stories in the minds of multiple individuals across a culture." The Tinai theory suggests that the ecology has a huge impact on the minds of the individual who share a similar culture and therefore, it "should" be reflected on the stories with the ecological tract as its backdrop. The minds of the individual are reflected in the Uripporul of the Agattinaiyiyal in Tholkappiyam. This makes the Tinai theory and Tholkappiyam to study the "ecology-languagestories" interaction in a systematic approach. While Arran Stibbe (2015) uses the term from an eco-critical viewpoint, Tholkappiyam emphasizes the need for looking into ecolinguistics from a socio-cultural-literary perspective.

Alwin Fill (2014), through the article "Ecolinguistics as a European idea", justifies on how the cause and the intent of ecolinguistics very close to the studies and theories propounded by the Europeans through various evidences. Alwin Fill (2014) claims a dichotomy between the ecolinguistic approaches of the American and European and explains how ecolinguistics takes a practical approach through the European. The American Ecolinguistics Tradition that began with Eliar Haugen and his idea "The ecology of language" uses the term "ecology" in more of a metaphorical sense. Whereas, on the contrary, the "European ecolinguistics takes ecology literally, as it were, and explores the role of language in the current ecological and environmental crisis." But, after understanding the ecolinguistic aspect of Tholkappiyam, we can see that the belief of "Ecolinguistics as a western idea" needs to be reconsidered. Language, culture and ecology goes hand in hand. In building language, stories and linguistic culture, ecology plays a crucial role. As Tholkappiyam suggests, language and culture are the offsprings of ecology and topography. Hence, the language-ecology interaction is not a recent evolution but fundamental to the evolution of language itself. Such language-ecology interaction discussed from a linguistic perspective can exist in other culture too way before the discipline was brought forth in the $20^{\text {th }}$ Century. As Sibo Chen (2016) recommends, ecolinguistics "should be locally grounded yet globally minded by incorporating non-western epistemologies for a better understanding of complexhuman-nature relations." Therefore, it is crucial to explore the non-western ecolinguistic perspectives like Tholkappiyam for the field to be studied and incorporated across geographical boundaries.

\section{References}

Alphonsa, S J. (2017). Tinai as a Ecocritical Concept. International Journal of English Language, Literature in Humanities.

Chen, Sibo. (2016). "Language and Ecology: A Content Analysis of Ecolinguistics as an Emerging Research Field". Ampersand.

Fill, A., \& Mühlhäusler, P. (2001). The ecolinguistics reader: language, ecology, and environment. London: Continuum.

Ganesh, K N. (2011). Space-Time, Event and Expression in Early Tamil Texts: Historicising Tolkappiyam. Indian Historical Review.

Haugen, E. (1972). The ecology of language. Stanford University Press, Redwood City 
Ingold, T. (2000). The perception of the environment: Essays on livelihood, dwelling and skill. Routledge, New York

Katz, E. (2000). Against the inevitability of anthropocentrism. In: Katz E, Light A, Rothenberg D (eds) Beneath the surface: Critical essays in the philosophy of deep ecology. The MIT Press, Cambridge, pp 17-42

LeVasseur, T. (2014) Environmental philosophy in a post-ice cap north polar world. Environmental Ethics Levins R, Lewontin R (1985) The dialectical biologist. Harvard University Press, Cambridge

Mühlhäusler, P. (2003). Language of environment, environment of language: a course in ecolinguistics. Battlebridge, London, UK

Murugan, V. (2000). Tolkappiyam in English. Institute of Asian Studies. Chennai.

Naess, A. (1995). The shallow and the long range, deep ecology movement, in A. Drengson and Y. Inoue (eds) The deep ecology movement: an introductory anthology. Berkeley, CA: North Atlantic Books.

Steffensen, S. \& Fill, A. (2014). Ecolinguistics: the state of the art and future horizons. Language Sciences 41(6): 25.

Lakoff, G. and Johnson, M. (1980). Metaphors we live by. Chicago, IL: University of Chicago Press.

Lakoff, G. \& Wehling, E. (2012). The little blue book: the essential guide to thinking and talking democratic. New York: Free Press.

Sapir, Edward. (1912). Language and Environment. Selected Writings in Language Culture and Personality. University of Californial Press, Berkley.

Somasundaram, O. (1991). The Tamil Anatomy of Happiness, Anger, Fear and Bewiderment. Indian Journal of Psychological Medicine, 14(2).

Stibbe, A. (2012) Animals erased: Discourse, ecology, and reconnection with the natural world. Wesleyan University Press, Middletown

Stibbe, A. (2012) Ecolinguistics and globalization. In: Coupland N (ed) The handbook of language and globalization. Wiley-Blackwell, Chichester.

Taylor, B. (2005) Religious studies and environmental concern. In: Taylor B (ed) The encyclopedia of religion and nature. Continuum, New York.

Thamburaj, K P., \& Ponniah K. (2016). Hierarchical Grammatical Tagging for Tinai (Landscape) of Cankam Tamil Literature. Indian Journal Of Science and Technology 9(1).

${ }^{1}$ Ms. V Shri Vaishali is a research scholar from VIT, Vellore, working on a comparative study between Internet Linguistics and the orthographic rules of Tholkappiyam.

${ }^{2}$ Dr. S. Rukmini is a Sr. Assistant Professor of English at VIT, Vellore. She has presented and published over 30 research articles and projects. Her specialization is related to a cross-cultural approach towards Indology and Digital Humanities. 